\title{
Peristiwa Diglosia Dalam Masyarakat Jawa Kuna: Suatu Interpretasi Linguistis Atas Kehadiran Unsur Serapan Bahasa Sanskerta Di Dalam Prasasti Bahasa Jawa Kuna Abad 9 - 10 Masehi
}

\author{
Kayato Hardani
}

Keywords: inscription, literature, assimilation, language, ancient java, diglossia

\section{How to Cite:}

Hardani, K. (2007). Peristiwa Diglosia Dalam Masyarakat Jawa Kuna: Suatu Interpretasi Linguistis Atas Kehadiran Unsur Serapan Bahasa Sanskerta Di Dalam Prasasti Bahasa Jawa Kuna Abad 9 - 10 Masehi. Berkala Arkeologi, 27(1), 1-18. https://doi.org/10.30883/jba.v27i1.939

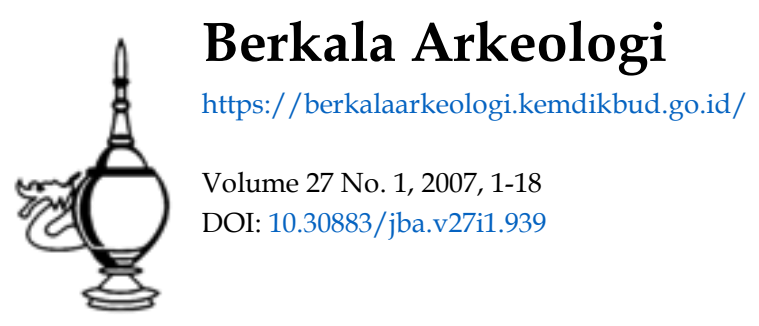

\section{(i) (2)}

This work is licensed under a Creative Commons Attribution-NonCommercial-ShareAlike 4.0 International License. 


\title{
PERISTIWA DIGLOSIA \\ DALAM MASYARAKAT JAWA KUNA : \\ SUATU INTERPRETASI LINGUISTIS ATAS KEHADIRAN \\ UNSUR SERAPAN BAHASA SANSKERTA DI DALAM \\ PRASASTI BAHASA JAWA KUNA \\ ABAD 9 - 10 MASEHI
}

\author{
Kayato Hardani \\ (Balai Pelestarian Peninggalan Purbakala Yogyakarta)
}

\section{Bahasa dalam budaya yang dinamis}

Bahasa sebagai sebuah gejala dan kekayaan sosial tak akan pernah berhenti melaju sejalan dengan perkembangan pemakaiannya. Pemikiran manusia dan tingkah laku manusia selalu ditandai oleh satu gejala alami, yakni perubahan. Perubahan adalah ciri pembeda yang berkadar universal dari umat manusia. Perubahan tingkah laku berbahasa terjadi pada setiap. kawasan kehidupan dalam setiap ruang dan waktu dari suatu suasana ke suasana lainnya, semua ini akan menyebabkan perubahan-perubahan aturan-aturan dan norma. Bahasa tidak pernah hadir dalam kehampaan, karena akan selalu diwarnai dengan perubahan-perubahan sosial. (Alwasilah, 1984: 32)

Perubahan bahasa dapat terjadi karena pengayaan kosakata atau perubahan gramatikal. Perubahan ini dapat merupakan inovasi yang terjadi dalam diri bahasa tersebut melalui para penuturnya atau berubah akibat pengayaan dari unsur kosakata asing melalui interaksi dan komunikasi antarpenutur bahasa yang berbeda. Pengayaan unsur kosakata asing pada suatu bahasa dapat berupa unsur serapan atau pinjaman. Kata serapan / pinjaman (borrowing/loan words) diartikan sebagai proses pengambilan dan penggabungan sejumlah unsur lingusitik lain dengan unsur linguistik yang asli dari suatu bahasa (Arlotto, 1972: 182).Di dalam pewarisan unsur-unsur bahasa, termasuk di dalamnya unsur serapan akan terjadi dua bentuk kemungkinan, yaitu pewarisan dengan perubahan (inovation) dan pewarisan tanpa perubahan ( retention). Unsur inovasi pada suatu bahasa dapat dibedakan menjadi dua yaitu inovasi internalyang merupakan pemunculan unsur-unsur kebahasaan yang baru dengan 
dengan memanfaatkan potensi bahasa dari dalam (Mahsun, 1995: 86) sedangkan inovasi yang muncul akibat pengaruh bahasa dari wilayah lain disebut sebagai unsur inovasi eksternal, biasanya unsur ini disebut sebagai unsur pinjaman / borrowing. (Mahsun, 1995: 88) Retensi merupakan unsur warisan dari bahasa asal yang tidak mengalami perubahan pada bahasa sekarang. (Fernandez, 1996: 22).

Peminjaman unsur bahasa asing adalah sebagai satu ciri kedinamisan budaya. Suatu kebudayaan tidak mungkin menjaga kepribadian dengan cara membatasi perkembangan unsur-unsurnya. Hal yang paling menonjol dari unsur kebudayaan adalah bahasa. Bahasa hanya dapat berkembang dan memperkaya diri bila terbuka serta mau menerima pengaruh lingkungan dengan tujuan untuk memperluas keperluan penggunaan kata dan penyusunan istilah baru. (Soebadio, 1987: 78). Layaknya kebudayaan, bahasa pun jarang mencukupi kebutuhannya sendiri. Kebutuhan menjalin kontak dengan bahasa lain telah mengakibatkan penuturnya secara langsung maupun tidak langsung berinteraksi dengan penutur bahasa lain yang mempunyai posisi dominan secara budaya. Hubungan interaksi tersebut terjadi akibat hubungan perdagangan atau saling tukar menukar barang maupun ilmu pengetahuan.

Kepulauan Nusantara memiliki kekayaan bahasa yang sangat beragam. Di dalam sejarah perkembangannya sejumlah bahasa-bahasa Nusantara mendapat pengaruh dari bahasa asing, seperti bahasa Sanskerta, Arab dan beberapa bahasa Eropa. Sejumlah bahasa Nusantara yang secara langsung memperoleh pengaruh langsung dari bahasa Sanskerta antara lain bahasa di Palembang, Jawa, Bali dan sebagian kecil bahasa di Kalimantan. Pengaruh bahasa Sanskerta di Nusantara ini berlangsung secara langsung dan tidak langsung. Pengaruh secara langsung terjadi pada peradaban-peradaban kuna di Indonesia seperti kerajaan di kawasan semenanjung Malaka, Sriwijaya, Kutai dan kerajaan-kerajaan di Jawa. Pengaruh secara langsung ini diperkirakan terjadi akibat kontak langsung seperti perdagangan atau hubungan keagamaan dengan penutur bahasa Sanskerta, sedangkan pengaruh secara tidak langsung adalah berupa peminjaman unsur bahasa Sanskerta yang terlebih dahulu dipinjam oleh bahasa lain. Misalnya adanya unsur bahasa Sanskerta dalam bahasa Indonesia (Melayu Modern) yang diperoleh dari pinjaman bahasa Jawa Kuna dan Melayu Kuna. (Gonda, 1952: 33) Dengan kedatangan pengaruh India 
bersama bahasa Sanskertanya ini diyakini telah memperkaya khasanah kebahasaan dalam bahasa-bahasa Nusantara.

Manusia sebagai mahkluk sosial dapat dicirikan dengan sifatnya yang selalu ingin berinteraksi dan berkomunikasi dengan manusia lain dalam satu kebudayaan maupun dengan manusia dari kebudayaan yang berbeda. Di dalam pandangan studi komunikasi, konsep interaksi antarbudaya lebih sempit bila dibanding komunikasi antarbudaya. Interaksi menggambarkan keadaan hubungan antara tindakan yang satu dengan yang lain yang belum tentu semua tindakan itu ditukar dan dimaknakan bersama. Tindakantindakan tersebut dipengaruhi oleh skema kognitif termasuk skema-skema yang mengatur susunan interaksi antara individu (Liliweri, 2001: 8) Interaksi dan komunikasi tersebut dapat menyebabkan keragaman atau bahkan perubahan pada masing-masing kebudayaan yang terlibat langsung dalam proses tersebut.

Di dalam proses interaksi dan komunikasi tersebut, bahasa mempunyai peran yang yang penting sebagai sarana transfer penyampaian ide dan gagasan dalam satu masyarakat bahasa yang sama maupun masyarakat bahasa yang berbeda. Dengan adanya interaksi dan komunikasi antar masyarakat bahasa yang berbeda, akibatnya akan menimbulkan adanya kontak bahasa. Kontak bahasa tersebut terjadi karena seorang individu atau sekelompok individu yang dengan sengaja ingin mempelajari bahasa kedua selain bahasa aslinya. Selanjutnya, kontak bahasa akan semakin terjalin bila dua bahasa yang berbeda digunakan secara bergantian oleh penutur yang sama. (Ariyanto, 1998: 10-11). Akibat kontak bahasa tersebut maka, di dalam masyarakat akan terdapat individu-individu yang terbiasa dalam memakai dua bahasa dalam satu masyarakat bahasa yang digunakan untuk berkomunikasi dalam aktivitas kehidupannya, peristiwa semacam ini disebut sebagai bilingualisme. Penyebutan semacam akan menjadi lain jika individu-individu tersebut hanya mampu atau sanggup untuk berganda bahasa, maka istilah yang dipakai adalah bilingualitas (Nababan, 1991: 26).

Peristiwa kebahasaan yang berupa bilingualisme akan dibedakan dengan peristiwa diglosia. Meskipun kedua peristiwa tersebut pada dasarnya memiliki kesamaan yaitu perihal hidupnya dua buah bahasa atau lebih dalam satu masyarakat masyarakat bahasa. Diglosia lebih berkaitan dengan pemakaian dua bahasa yang disesuaikan dengan peranan dan fungsinya 
masing-masing dalam konteks sosial. (Ariyanto, 1998: 17) Peristiwaperistiwa semacam bilingualisme, bilingualitas dan diglosia secara langsung maupun tidak langsung akan memunculkan penerimaan kosakata asing dalam asing bahasa pribumi. Di dalam tulisan ini akan mencoba mengamati gejala kebahasaan khususnya diglosia sebagaimana tersirat di dalam pemakaian unsur serapan bahasa Sanskerta pada prasasti-prasasti abad 9 hingga 10 Masehi.

\section{Bahasa Sanskerta dan Bahasa Jawa Kuna : Menembus Batas} Bahasa Sanskerta secara genealogis termasuk dalam rumpun Bahasa Indo Eropa. Rumpun Bahasa Indo Eropa terdiri atas cabang-cabang Bahasa Jerman, Armenia, Baltik, Slavia, Roman, Keltik, Gaulis dan Indo Iranika. (Keraf, 1995: 25). Cabang keluarga Bahasa Indo Eropa di Asia yang terbesar adalah kelompok Indo Iranika. Kelompok ini terdiri dari dua subkelompok yaitu Iranika dan Indika / Indo Arya. (Bloomfield, 1995: 61). Subkelompok Bahasa Indo Arya dalam perkembangannya secra umum terbagi mejadi tiga periode yaitu, periode kuna (Old Indo Aryan) sekitar \pm 1500 SM, periode pertengahan (Middle Indo Aryan) sekitar $\pm 500 \mathrm{SM}$ dan terakhir adalah periode modern (Modern Indo Aryan) sekitar $\pm 1000 \mathrm{M}$. pembagian antar periode tersebut hanya berrsifat perkiraan, sebab keberadaan antar periode pada kenyataannya saling tumpang tindih, bahkan penggunaan bahasa dari periode yang lebih tua tetap dipakai pada periode yang lebih muda. (Embree, 1988: 130-132).

Fase awal dari periode kuna (Old Indo Aryan) terwakili oleh bahasa yang digunakan dalam teks Weda. Weda yang tertua adalah Rig Weda yang merupakan kumpulan mantra-mantra religius. Teks ini diperkirakan berasal dari milenium kedua sebelum masehi. Teks-teks Weda lainnya yang juga berasal dari fase ini antara lain Sama Weda, Yajur Weda dan Atharwa Weda. Tradisi Weda pada tahap selanjutnya menghasilkan karya sastra berbentuk prosa seperti Brahmana dan Upanishad. Bahasa yang dipakai dalam teks-teks Weda selanjutnya disebut sebagai masa Weda Awal, sedangkan bahasa yang dipakai dalam Upanishad dan Brahmana disebut sebagai masa Weda Akhir. Dari perbedaan masa tersebut dapat diketahui migrasi penutur Bahasa Indo Arya dari arah barat daya menuju ke wilayah pusat dan timur India (Embree, 1988: 130-132). Bahasa yang dipakai di dalam teks-teks Weda merupakan bahasa kesastraan yang dipakai oleh 
para pendeta. Bahasa ini dikenal sebagai vaidiki bhasa. Selain itu di luar kesastraan Weda dikenal Laukiki bhasa yakni bahasa yang dipakai rakyat kebahyakan. Bahasa masyarakat kebanyakan ini kemudian diperbaiki dan ditata menurut aturan tata bahasa sehingga bebas dari kata-kata keliru yang biasa muncul. Pada abad pertama milenium pertama sebelum masehi, aturan-aturan tatabahasa dari teks Weda mulai diabaikan seperti penghilangan infleksi, penyederhanaan tatahbahasa, peminjaman unsur bahasa non-arya, akibatnya bentuk kata yang lama menghilang atau bahkan kehilangan makna aslinya (Basham, 1988: 387). Sehingga juga disebut sebagai samskerta yakni sesuatu yang sudah diperbaiki atau dibersihkan. Penamaan dengan istilah bahasa Sanskerta merupakan penamaan yang tidak didasarkan asal bangsa pemakainya atau letak geografisnya.

Ahli tatabahasa yang terkenal dalam upaya pemurnian kembali bahasa dengan aturan tatabahasa adalah Panini ( $\pm 400 \mathrm{SM})$. Melalui karyanya yang berjudul Astadhyayi, Bahasa Sanskerta menjadi dibakukan dan berkembang sejalan dengan peraturan tatabahasa yang telah ia buat. Dengan adanya aturan tatabahasa yang dibuat Panini tersebut, akibatnya muncul istilah prakrita "bahasa umum, sederhana". (Sharma, 1985: 3). Bahasa Prakrit merupakan dialek umum yang berkembang secara alami. (Basham, 1988: 389). Karya Panini ini selanjutnya disempunakan olek Katyayana ( \pm 300 SM) dan Patanjali ( \pm 200 SM). (Embree, 1988: 130-132). Karya Panini ini dapat dianggap sebagai usaha yang menstabilkan tatabahasa Sanskerta dari karya-karya ahli tatabahasa sebelumnya seperti Yaska dalam Nirukta dari abad V SM. Panini dalam upaya standarisasi Bahasa Sanskerta diyakini menggunakan lingua franca dari daerah barat laut yang digunakan kaum agamawan dan kemudian dipakai pula dalam bahasa pemerintahan. (Basham, 1988: 389) Bahasa Sanskerta mulai dipakai sebagai bahasa ketatetapan resmi yakni pada masa dinasti Úlaka dari daerah Ujjayinî (Basham, 1988: 389).

Pengaruh India diindikasikan mulai menyebar di kawasan Asia Tenggara termasuk Indonesia antara abad II hingga III Masehi. Penyebaran ini diperkirakan melalui perdagangan laut. Kurun waktu tersebut bersamaan dengan dikenalnya teknologi transportasi laut, akibatnya pengaruh India mulai menyebar di wilayah persinggahannya yang kemudian menjadi dasar pokok dalam pendirian kerajaan-kerajaan di berbagai wilayah Asia Tenggara. Pengaruh India yang berupa ajaran agama Hindu-Budha masuk ke wilayah 
Indonesia bagian barat diperkirakan dibawa oleh guru-guru agama atau penduduk asli yang kembali ke negeri aslanya setelah lama bermukim di India. (Damais, 1995: 5). Para guru agama dan kaum terpelajar tersebut diperkirakan sebagai orang-orang yang mengenalkan Bahasa Sanskerta ke dalam rumpun Bahasa Austronesia yang termasuk di dalamnya Bahasa Jawa Kuna.

Rumpun Bahasa Austronesia yang juga disebut sebagai Melayu Polinesia mencakup bahasa-bahasa di wilayah Indonesia, Melanesia dan Polinesia. Penutur bahasa-bahasa Austronesia tersebar luas mulai dari sebelah barat yaitu Pulau Madagaskar hingga ke sebelah timur yaitu Pulau Paskah, serta di sebalah utara yaitu Pulau Formosa hingga ke selatan mencapai New Zealand. Hanya terdapat dua perkecualian kecil yaitu orang asli di Malaysia pedalaman yang menuturkan bahasa-bahasa rumpun Austroasia dan beberapa suku di Indonesia bagian timur yang menuturkan bahasa-bahasa Papua. (Bellwood, 2000: 142).

Rumpun Bahasa Austronesia mencakup bahasa-bahasa yang masih digunakan maupun bahasa yang telah punah. Bahasa-bahasa yang telah punah tersebut biasanya meninggalkan bukti tertulis yang menunjukkan tingginya peradaban di masanya. Bahasa-bahasa tersebut antara lain Bahasa Cham dan Bahasa Jawa Kuna yang keduanya termasuk dalam subkelompok Bahasa Melayu Polinesia Barat. Subkelompok Melayu Polinesia Barat meliputi bahasa di Filipina, Vietnam, Madagaskar, Malaysia, Sumatra, Jawa, Kalimantan, Sulawesi, Bali, Lombok, Sumbawa bagian barat serta dua bahasa di Mikronesia barat yaitu Bahasa Palau dan Chamoro. Bahasa-bahasa yang digunakan pada kebudayaan kuna tersebut, di dalam studi perkembangan bahasa hanya disebut sebagai old language bukan sebagai bahasa awal (proto language). Studi mengenai bahasa awal, khusus di Pulau Jawa telah dilakukan oleh Bernd Nothofer yakni dengan merekonstruksi Proto Bahasa Melayu Jawa ke dalam empat bahasa yaitu Bahasa Sunda, Melayu, Jawa dan Madura. (Nothofer, 1975). Bahasa Jawa Kuna merupakan salah satu bentuk perkembangan dari Bahasa Proto Malayo Javanic yang merupakan bahasa yang dipakai oleh masyarakat bahasa di Jawa pada masanya. Keberadaan Bahasa Jawa Kuna, di kawasan Pulau Jawa pada khususnya serta di kawasan Asia Tenggara pada umumnya, pada abad VI Masehi keberadaannya pernah dideskripsikan oleh sumber Cina yakni dengan penyebutan Kun Lun. Istilah 
Kun Lun digunakan untuk menyebut bahasa yang dipakai penduduk di daerah Sumatra, Jawa dan juga Campa.' Hal ini dapat disebabkan karena bahasa-bahasa di berbagai daerah tersebut terdengar sebagai bahasa yang sama oleh para musafir Cina, selain itu bahasa-bahasa tersebut secara linguistis memang serumpun yang di dalamnya banyak dijumpai istilahistilah dari Bahasa Sanskerta. (Zoetmulder, 1994: 6-7).

Berbeda dengan kemunculan dan perkembangan Bahasa Sanskerta yang dapat ditelusuri kembali dari masa yang paling tua melalui teks-teks Weda, Bahasa Jawa Kuna dalam kemunculannya dapat dikatakan muncul dengan tiba-tiba yakni dari suatu masa tanpa tinggalan tertulis tiba-tiba muncul tinggalan tertulis yang telah memiliki ciri-ciri perkembangan lebih lanjut sebagai satu bahasa Nusantara. Hal ini dipahami bila hanya didasarkan atas temuan prasasti berbahasa Jawa Kuna yang paling tua yaitu, Prasasti Sukabumi ( $804 \mathrm{M})$. Prasasti Sukabumi atau Prasasti Hariñjing merupakan prasasti tinulad, di dalam prasasti ini terdapat dua angka tahun yaitu $784 \mathrm{C}$ dan 921 Ç. Di dalam prasasti ini, Bahasa Sanskerta dari tahun 784 Ç dimasukkan dalam prasasti baru yang berbahasa Jawa Kuna dengan angka tahun 921 Ç.) Meskipun demikian, tidak berarti di Pulau Jawa sebelum tahun tersebut belum terdapat budaya tulis, tetapi tahun tersebut hanya merupakan titik awal ditemukannya prasasti berbahasa Jawa Kuna. Pada masa yang lebih tua dari angka tahun Prasasti Sukabumi di Pulau Jawa sebenarnya telah terdapat tinggalan tertulis tetapi menggunakan Bahasa Sanskerta (kurun waktu 732 M hingga 792 M) dan Bahasa Melayu Kuna (792 M). Prasasti yang berbahasa Sanskerta adalah Prasasti Sañjaya (654. Ç), Prasasti Hampran (672 Ç), Prasasti Kañjuruhan (682 Ç), Prasasti Kalasan (700 Ç), Prasasti Kelurak (704 Ç) dan Prasasti Abhayagiriwihara (714 Ç), sedangkan prasasti yang berbahasa Melayu Kuna adalah Prasasti Manjuçrigrha (714 Ç). Dari prasasti-prasasti tersebut menunjukkan bahwa di Pulau Jawa pada kurun waktu abad XIII hingga IX Masehi, terdapat tiga bahasa yang hidup dan dikenal oleh masyarakat. Bahasa Jawa Kuna untuk pertama kali ditemukan dalam prasasti berangka tahun $804 \mathrm{M}$, hal ini tentu tidak dapat dipungkiri bahwa sebelumnya pasti terdapat budaya tulis yang menggunakan Bahasa Jawa Kuna dengan media yang tidak awet seperti kulit kayu, kulit binatang atau pada daun. 


\section{Peristiwa Diglosia Dalam Masyarakat Jawa Kuna}

Penerimaan kosakata dari suatu bahasa asing dapat diamati melalui bahasa wicara maupun bahasa tulis. Munculnya pembedaan antara bahasa wicara dan bahasa tulis dibedakan atas dasar penghadirannya dalam proses komunikasi. Komunikasi antarpribadi berwujud perilaku simbol. Karena pesan-pesan komunikasi dinyatakan dalam simbol-simbol verbal dan nonverbal yang mewakili gagasan tertentu. (Liliweri, 2001:6) Bahasa wicara ( verbal visual ) dipakai dalam komunikasi antarindividu sebagai komunikan dan komunikator yang terbatas oleh ruang dan waktu, lain halnya dengan bahasa tulis ( nonverbal visual) yang tidak dibatasi oleh ruang dan waktu. Kedua bentuk penghadiran bahasa tersebut pada dasarnya memiliki korelasi yang tidak dapat dipisahkan. Bahasa tulis dapat dianggap sebagai rekaman dari bahasa wicara dan seringkali bahasa tulis mengawetkan bentuk-bentuk tua dari bahasa wicara yang kini tidak dipakai kembali. (Gelb, 1963: .223) Di dalam pembuatan rekaman atas wicara dalam bentuk tulisan pada dasarnya merupakan suatu kegiatan yang jauh berbeda, karena pada umumnya bahasa tulis tidak secara keseluruhan paralel dengan bahasa wicara. (Bloomfield, 1964: 392) Keterkaitan antara bahasa wicara dan bahasa tulis dapat digambarkan secara sederhana melalui bagan di bawah ini:

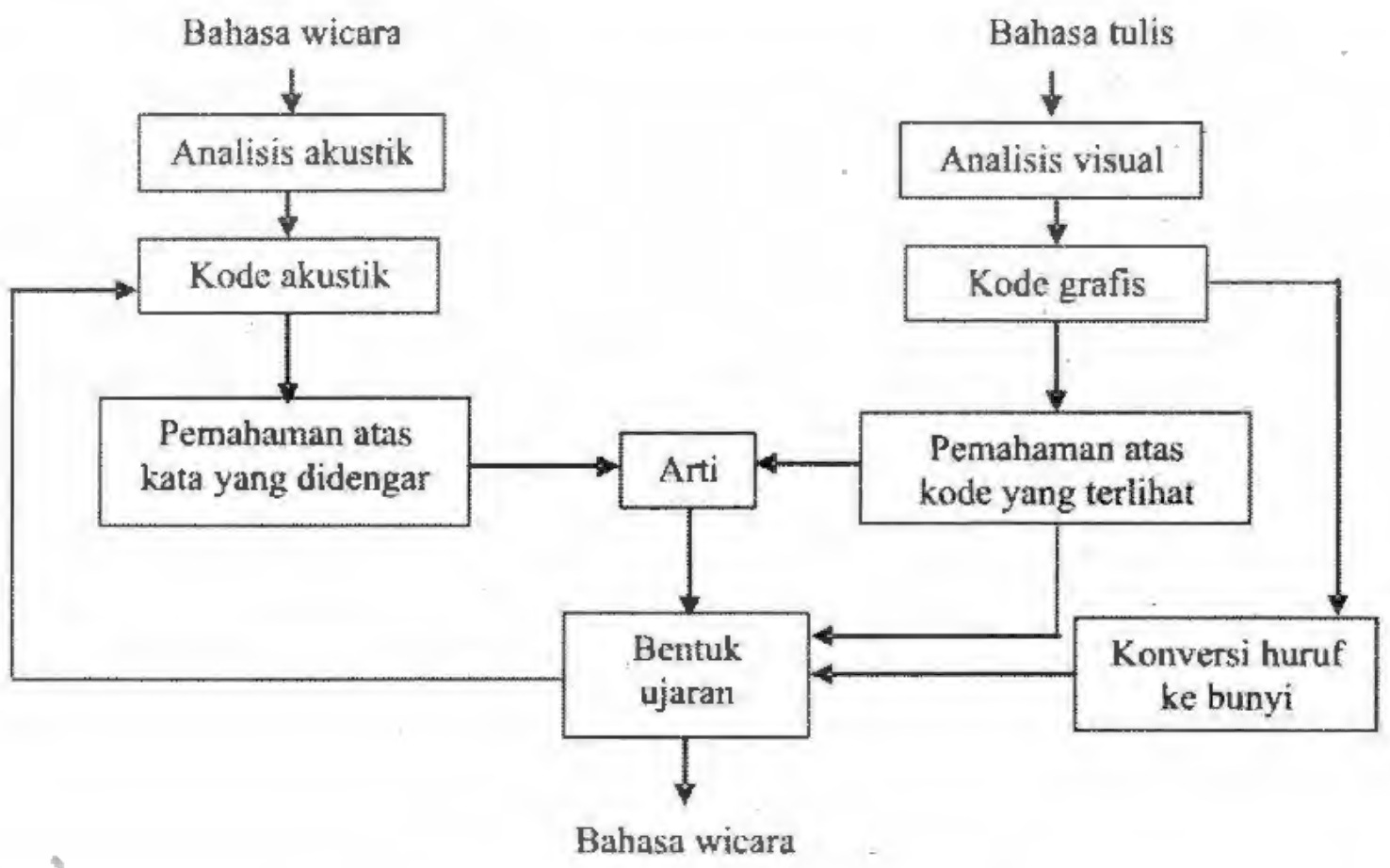

Keterkaitan antara bahasa wicara bahasa tulis (Crystal, 1992 : 211) 
Dua bentuk penghadiran bahasa tersebut pada dasarnya telah memungkinkan untuk terjadinya pewarisan sekaligus pengawetan suatu tradisi dari satu generasi ke generasi berikutnya. (Clark, 1969: 222) Hal tersebut akan semakin dipahami jika dikaitkan dengan kedudukan bahasa sebagai mediasi pikiran, perkataan dan perbuatan sekaligus dipakai untuk menerjemahkan persepsi, sikap dan kepercayaan manusia tentang dunia para penuturnya. (Liliweri, 2001: 129)

Prasasti sebagai salah satu bentuk bahasa tulis, di dalamnya juga memuat fenomena kebahasaan sebagai hasil dari kontak bahasa yaitu berupa pemakaian unsur serapan bahasa asing, dalam hal ini adalah bahasa Sanskerta. Di pulau Jawa pada abad 9 hingga 10 Masehi penulisan unsur serapan bahasa Sanskerta dalam prasasti tentunya dapat dipakai sebagai indikator pemakaiannya dalam bahasa wicara para penulisnya, atau bahkan lingkungan sosial yang lebih luas. Adanya unsur serapan dari bahasa Sanskerta ke dalam bahasa Jawa Kuna dapat digunakan sebagai petunjuk bahwa di pulau Jawa pernah terjadi kontak bahasa antarkedua penuturnya pada suatu masa.

Di pulau Jawa sejak abad 8 Masehi melalui tinggalan prasasti dijumpai adanya tiga budaya yang kesemuanya telah saling melakukan kontak budaya termasuk kontak bahasa. (Kartakusuma, 1988: dan Darmosoetopo, 1998). Ketiga bahasa tersebut adalah bahasa Melayu Kuna, Jawa Kuna dan bahasa Sanskerta. Masing-masing bahasa tersebut memiliki peran, kedudukan dan fungsi yang berbeda. Bahasa Jawa Kuna merupakan bahasa pribumi yang dipakai sebagai bahasa pergaulan umum, sedang bahasa Melayu Kuna diperkirakan dipakai untuk kepentingan perdagangan dan terakhir bahasa Sanskerta merupakan bahasa yang dipakai dalam kepentingan keagamaan. (Darmosoetopo, 1998: 36). Dengan adanya pembagian bahasa menurut fungsi dan kedudukannya dalam konteks sosial, maka pada akhirnya mengakibatkan bahasa yang satu akan memiliki prestise yang tinggi dibanding bahasa yang lainnya. Pandangan semacam ini bersifat subyektif bila dipandang dari sisi kelompok masyarakat pemakai bahasa yang bersangkutan, akan tetapi pada kenyataan memang terjadi hal yang demikian (Ariyanto, 1988 hal.9). Bahasa dengan prestise yang lebih tinggi selanjutnya dianggap sebagai ragam 
bahasa tinggi yang dipakai dalam situasi resmi. Ragam semacam ini telah mengenal bahasa tulis sehingga lebih sering dipakai sebagai bahasa sastra di kalangan pemakainya serta telah mengalami pembakuan melalui kodifikasi-kodifikasi yang rumit. (Suhardi, 1996: 91). Sebaliknya, bahasa yang tidak dipakai pada situasi tidak resmi adalah ragam bahasa yang dipakai sehari-hari. Ragam ini tidak mengenal bahasa tulis. Penguasaan atas ragam-ragam tersebut dapat dipakai sebagai penanda terpelajar atau tidaknya seseorang. (Ibid, hal.92) Situasi kebahasaan semacam ini disebut sebagai diglosia. Istilah diglosia untuk pertama kali dipakai oleh Charles A. Ferguson (1964) untuk melukiskan situasi kebahasaan yang terdapat di Yunani, negara-negara Arab, Swiss dan Haiti.

Dengan melihat fakta atas peran dan kedudukan bahasa-bahasa di Jawa pada abad 8 hingga 10 Masehi tidak diragukan bahwa bahasa Saskerta merupakan ragam bahasa tinggi. Bahasa Sanskerta merupakan bahasa yang dikodifikasikan secara rumit pada tataran fonologi maupun morfologi. Dalam bahasa Sanskerta, akar kata akan berubah menjadi kata turunan (derivasi) yang didasarkan atas perbedaan subkelas kata atas dasar jumlah (singular, dual dan plural), jenis (femininum, netrum, dan maskulinum) serta tingkat persona (penutur, pendengar, persona III). Bahasa Sanskerta lebih banyak dijumpai dalam teks-teks tertulis keagamaan maupun kesusastraan. Bagi seorang individu yang memiliki kemampuan untuk menguasai bahasa Sasnkerta dianggap sebagai orang yang berpendidikan. Sebaliknya dengan bahasa Melayu Kuna dan Jawa Kuna, kedua bahasa Nusantara ini dipakai sebagai bahasa pergaulan umum bagi para penuturnya dan digolongkan sebagai ragam bahasa rendah. Ragam bahasa rendah umumnya tidak mengenal bahasa tulis, namun pada budaya Melayu Kuna dan Jawa Kuna kedua-duanya mengenal bahasa tulis. Aksara yang diipakai dalam sejumlah tinggalan tertulis yang ditemukan di Jawa dan Sumatra diasumsikan adalah sebagai bentuk adopsi dan adaptasi dari sebuah aksara di India, ( periksa Molen, 1985 dan Damais, 1995).

Ferguson, mengidentifikasikan peristiwa diglosia muncul melalui adanya proses belajar melalui lembaga pendidikan formal. (Ferguson, 1964: hal. 435.) Pendidikan formal ini dapat disetarakan dengan saluran akulturasi dalam proses perubahan budaya. Bentuk pendidikan formal sebagai 
saluran transfer budaya India ke dalam budaya Jawa belum dapat diketahui dengan pasti. Diperkirakan pada masa itu terdapat institusi formal yang berupa pusat studi keagamaan dan keberadaannya dilindungi dan dijamin oleh kerajaan. Meskipun dalam sejumlah prasasti ditemukan gelar dang âcâryya yang secara etimologi berarti "guru terutama dari kaum Brahmana", tetapi prasasti tidak menyebut dengan pasti tentang institusi formal yang terutama mengkhususkan pada pengajaran keagamaan, termasuk di dalamnya pengajaran kitab agama dan kesastraan.

Di dalam prasasti yang berasal dari kurun waktu abad 9 hingga 10 Masehi menyebutkan tentang bangunan-bangunan keagamaan yang memperoleh tanah sima antara lain prasada, dharmma, kabikuan, bihara, patapan, parhyangan, caitya, kuti dan cala yang masing-masing memiliki fungsi berbeda-beda. (Darmosoetopo, 2003 : 203) Dari sekian jenis bangunan keagamaan tidak diketahui dengan pasti bangunan manakah yang berfungsi sebagai institusi pengajaran agama. Sebuah contoh yang menarik untuk dijadikan perbandingan adalah informasi dari prasasti Nalanda ( $\pm 860 \mathrm{M}$ ). Di daerah Nalanda yang kini menjadi wilayah dari Benggala, pada abad 8 hingga 10 Masehi merupakan pusat pengajaran agama Budha yang terkenal di kawasan semenanjung Malaya dan Asia. Pusat pengajaran ini oleh sejumlah ahli disetarakan sebagai universitas. Hal tersebut akan menjadi rasional bila di Jawa pada kurun waktu yang sama terdapat pusat pengajaran agama yang tentunya dalam skala lebih kecil. Berita Cina menyebutkan bahwa seorang agamawan bernama Houi Neng pada tahun $665 \mathrm{M}$ pernah tinggal di Jawa untuk menerjemahkan berbagai kitab naskah agama Budha ke dalam bahasa Cina dengan dibantu oleh agamawan pribumi yang bernama Jnanabhadra. (Damais, $1995: 88$ )

Sama halnya ketika I Tsing pada tahun 671 Masehi ketika ia singgah di Fo Shih (Sriwijaya) untuk mempelajari bahasa Sanskerta. Lebih lanjut dia menyatakan bahwa di Fo Shih banyak ditemukan pendeta Budha yang mempelajari banyak hal sebagaimana di India, jika seorang pendeta Cina ingin pergi ke barat untuk mengerti dan membaca teks Budha di India ia haruslah tinggal setahun atau dua tahun di Fo Shih, kemudian dia dapat pergi ke India tengah. (Collins, 2005: 9) Namun tidak diketahui dalam wujud apakah tempat para pendeta itu tinggal. Tentunya sebuah institusi formal 
yang memungkinkan terjadi kegiatan transfer ilmu agama dan tentu ilmu bahasa.

Institusi formal keagamaan selain sebagai pusat pengajaran agama dapat diasumsikan pula sebagai tempat dilakukannya kegiatan penerjemahan kitab maupun naskah keagamaan dan kesasastraan. Penerjemahan kitab kesastraan dari masa pra-Sindok yang sampai kini masih dapat diketahui adalah adalah Ramayana. ( Lebih lanjut lihat Zoetmulder, 1994:277). Selain itu, kisah Ramayana ternyata pada masa Dyah Balitung juga hidup sebagai sastra lisan ( atau dibacakan?), seperti yang terlihat dalam prasasti Wukajana "... si jaluk macaritta ramayana...". Dengan adanya kegiatan penerjemahan kitab-kitab berbahasa Sanskerta ke dalam bahasa Jawa Kuna maka secara langsung atau tidak langsung telah mempengaruhi perbendaharaan kosakata si penerjemah pribumi. Sebagai perbandingan adalah penelitian yang dilakukan oleh Edward P. Dozier yakni tentang kemunculan bahasa Spanyol dalam bahasa Indian suku Yaqui dan Tewa. Kemunculan kata tersebut disebabkan oleh usaha penerjemahan kitab suci berbahasa Spanyol ke dalam bahasa pribumi (. Dozier, 1964: 510 )

\section{Peran Citralekha}

Sebuah prasasti merupakan ciri idiolek dari seorang citralekha. Idiolek merupakan ciri bahasa seseorang. Idiolek-idiolek yang lebih banyak menunjukkan persamaan karen letak geografis yang berdekatan hingga memungkinkan komunikasi antarpenutur idiolek dapat dikategorikan sebagai dialek. Idiolek lebih sering dipengaruhi oleh faktor geografis dan sosiologis. Sebagaimana telah diuraikan di bagian awal bahwa seseorang yang menguasai ragam bahasa tinggi adalah orang yang terpelajar dan sering dipakai dalam situasi-situasi resmi. Citralekha sebagai penulis prasasti, tentunya ia adalah seorang yang berpendidikan. Jika diasumsikan bahwa di Jawa pada abad 9 hingga 10 Masehi tingkat buta huruf sangat tinggi di kalangan rakyat, maka citralekha dengan kemampuannya untuk membaca dan menulis menunjukkan bahwa ia berbeda dengan orang kebanyakan. Sebagai parameter perbandingan adalah sensus masa pemerintahan Kolonial di tahun 1930 menunjukkan bahwa penduduk 
Indonesia yang dapat membaca menulis hanya $6,44 \%$ dari jumlah penduduk sebesar 50 juta, dengan catatan bahwa sekitar $75 \%$ atau 40 juta bermukim di pulau Jawa dan Madura (Basri, 1975: 99 dan 127).

Suatu hal yang menarik ditunjukkan dari seorang citralekha yaitu ia adalah kaum bangsawan. Meskipun dijumpai pula citralekha dari golongan kaum agamawan dan rakyat biasa tetapi perbandingannya sangat sedikit Citralekha dari golongan bangsawan diketahui dari penulisan partikel penyebutannya yaitu rakai, samgat, sang hadean, dyah dan $p u$, sedangkan golongan agamawan memakai partikel dang acaryya. Citralekha dari golongan rakyat biasa diketahui dari partikel sang dan si. Hal tersebut menunjukkan bahwa kesempatan memperoleh pendidikan lebih didominasi oleh kaum bangsawan termasuk di dalamnya pengajaran kitab-kitab berbahasa Sanskerta, sedangkan munculnya golongan rakyat biasa sebagai citralekha adalah sebagai upaya mobilitas sosial vertikal. Dominasi oleh kaum bangsawan dalam hal penerimaan pengaruh India dapat dikaitkan degan asumsi bahwa budaya India pertama kali merasuk pada kalangan rajya yang kemudian mengembangkan budaya dengan berorientasi kepada pergaulan internasional. Citralekha dari golongan bangsawan diketahui dari penulisan partikel penyebutannya yaitu rakai, samgat, sang hadean, dyah dan $p u$, sedangkan golongan agamawan memakai partikel dang acaryya. Citralekha dari golongan rakyat biasa diketahui dari partikel sang dan si (Istiawan, 1991: 48).

Berikut adalah sebuah contoh kehadiran unsur bahasa Sanskerta di dalam prasasti Mantyasih I (907 Masehi) yang ditulis oleh Punta Tarka. Untuk kata dari bahasa Sanskerta dicetak tebal.

1. //O// swasti úakawarsâtîta 829 caitramâsa tithi ekâdaúi krsnapaksa tu $u$ œea wâra pûrwwabhadrawâdanaksatra ajapâdewatâ indrayoga tatkâla âjña úrî mahârâja rakai watukura dyah balitung úrî dha

2. rmmodaya mahâsambhu umingsor i rakarayân mapatih i hino halu sirikan wka halaran tiruan palarhyang manghûri wadihati makudur kumonakannikanang wanua i mantyâsih winih ni sawahnya satû muang a 
3. lasnya i munduan i kayu pañjang muang pomahan ing kuning wanua kagunturan pasawahanya ri wunut kwaih ni winihnya satû hamat 18 hop sawah kanayakân muang alasnya i susundara i wukir sumwing kapua wa

4. tak patapân sinusuk sîmâ kapatihana paknânya pagantyagantyana nikanang patih mantyâsih sânak lawasanya tlung tahun sowang kwaih nikanang patih sapunduh pu sna rama ni ananta pu kolâ rama ni dinî pu puñing

5. rama ni udal pu karâ rama ni labdha pu sudraka rama i kayut pinda prâna 5 samangkana kwaih nikanang patih inanugrahân muang kinon ta ya matûta sânak // sambandhanyan inanugrahân sangkâ yan makwaih buatthaji

6. iniwönya i ún̂ mahârâja kâla ni warangan haji lain sangke kapûjan bhatâra i malangkuœeœwara ing pûteúwara i kutusan i úilâbhedeúwara i tuleœwara ing pratiwarsa muang sangkâ yan antarâlika kataku

7. tan ikanang wanua ing kuning sinarabhârânta ikanang patih rumaksâ ikanang hawân nahan matang yan inanugrahâkan nikanang wanwa kâlih irikanang patih // kunang parnnahhanya tan katamâna de sang pangkur tawân tirip muang sa

8. prakâra ning mangilala drabya haji kring padam apuy tapa haji airhaji rataji makalangkang mangrumbai manimpiki manghûri limus galuh sambal paranakan kdi widu mangidung hulun haji mamrasi ityawamâdi tan hana deyan

9. tumamâ inya kunang yan wuara sukhadukhanya ikanang patih mantyâsih atah pramânâ iriya // mangasöâkan nikanang patih pask pask i tanda rakarayân sawyavasthâ ning manusuk sîmâ yathân yan mapagha dlâha ning dlâha

10. rakryân mapatih i hino mahâmantri úrî daksottama bâhubajrapratipaksaksaya inangsâan mas su 1 mâ 4 wdihan gañjar pâtrasisi yu 1 rakryân halu pu wîrawikrama rakryân sirikan pu wariga samarawikrâ .... 
Terlihat jika unsur bahasa Sanskerta diperlakukan sesuai keinginan citralekha yang merupakan bagian dari masyarakat Jawa Kuna atau lebih umum sebagai penutur salah satu bahasa rumpun Austronesia. Hal nyata yang jelas adalah perlakuan terhadap kosakata asing dengan meng-hibridkan dengan aturan-aturan tata bahasa yang jamak dipakai masyarakat bahasa Austronesia. Yakni terlihat adanya pemakaian afiks-afiks khas Jawa kuna, seperti sinarabharanta, inanugrahan, patapan, kapatihan. Penambahan berupakan awalan, akhiran dan sisipan bukan suatu hal yang lazim dipakai dalam bahasa Sanskerta. Selain itu, sejumlah unsur pinjaman bahasa Sanskerta dipakai secara selaras dalam tata kalimat secara keseluruhan, sehingga dimungkinkan sekali tidak akan menimbulkan gangguan dalam proses komunikasi nonverbal-visual bagi pembaca. Hal tersebut menunjukkan bahwa bahasa Jawa Kuna telah memperkaya perbendaharaan kosakatanya dengan meminjam dari bahasa Sanskerta, akibatnya unsur-unsur pinjaman tersebut seolah-olah merupakan bagian dari bahasa pribumi.

\section{Penutup}

Meskipun demikian, fenomena kehadiran bahasa Sanskerta di dalam prasasti-prasasti berbahasa Jawa Kuna abad 9 hingga 10 Masehi yang ditulis oleh citralekha-citralekha belum dapat diketahui dengan pasti perolehannya. Dari sisi linguistis bercampurnya kosakata asing dengan bahasa, pribumi dapat dikatakan sebagai indikator adanya peristiwa diglosia, tetapi di sisi lain terdapat fakta bahwa bahasa adalah suatu hal yang diwariskan. Adakah unsur-unsur bahasa Sanskerta yang dijumpai di dalam prasasti berbahasa Jawa Kuna dari abad 9 hingga 10 Masehi ini diwariskan dari masa-masa yang lebih tua, yakni oleh leluhur-leluhur penutur bahasa Jawa Kuna ketika pertama kali bersinggungan secara intens dengan budaya India dengan bahasa Sanskerta-nya?

Diperlukan suatu penelitian yang mendalam untuk mengetahui fenomenafenomena berbahasa di dalam prasasti yang dimulai dari masa paling awal hingga masa-masa paling muda. 


\section{KEPUSTAKAAN}

Alwasilah, A. Chaedar, 1984, Lingustik Suatu Pengantar, Bandung: Penerbit Angkasa

Ariyanto, 1998 "Peristiwa Alih Kode dan Campur Kode Dalam Masyarakat Jawa Yang Dwibahasawan ", Laporan Penelitian, Yogyakarta: Universitas Gadjah Mada.

Arlotto, Anthony, 1972, Introduction to Historical Linguistic, London: University Press of America.

Basham, A.L, 1988, The Wonder That Was India, London : Sidgwick and Jackson.

Basri, Yusmar (ed.), 1975 "Jaman Kebangkitan Nasional dan Masa Akhir Hindia Belanda", Sejarah Nasional Indonesia V, Depatemen Pendidikan dan Kebudayaan,

Bellwood, Peter, Prehistory of The Indo Malaysian Archipelago, diindonesiakan oleh T.W Kamil, 2000Prasejarah Kepulauan Indo Malaysia, Jakarta : PT. Gramedia Pustaka Utama.

Bloomfield, Lecnard, 1964, "Literate and Iliterate Speech ", dalam Dell Hymes, Language in Culture and Society, New York: Harper and Row Publisher.

Bloomfield, Leonard, 1995, Language, diindonesiakan oleh I.Sutikno, Bahasa, Jakarta : Penerbit PT. Gramedia Pustaka Utama.

Clark, Grahame, 1969, Archaeology and Society, New York: Barnes and Noble Inc

Collins, James T, 2005, Bahasa Melayu Bahasa Dunia Sejarah Singkat, Jakarta : Yayasan Obor Indonesia

Damais, Louis Charles, 1995 "Buddha di Indonesia ", dalam Epigrafi dan Sejarah Nusantara, Pilihan Karangan Louis Charles Damais, Jakarta : EFEO,

Damais, Louis Charles, 1995 "Tulisan-Tulisan Asal India di Indonesia dan Asia Tenggara daratan", dalam Epigrafi dan Sejarah Nusantara, Pilihan Karangan Louis Charles Damais, Jakarta: EFEO.

Darmosoetopo, R. (1998). Keberadaan Bahasa Melayu-Kuna Abad VII- IX C Di Jawa. Berkala Arkeologi, 18(1), 30-39.

https://doi.org/10.30883/jba.v18i1.774 
, 2003, Sima dan Bangunan Keagamaan di Jawa Abad IX - X

TU, Yogyakarta : Prana Pena.

Dozier, Edward P,1964, "Two Examples of Linguistic Acculturation: The

Yaqui of Sonora and Arizona and the Tewa of New Mexico", dalam Dell Hymes, Language in Culture and Society, New York: Harper and Row Publisher.

Embree, Ainslie T, (ed. ), 1988, Encyclopaedia of Asian History, volume ke-2, Charles Scribner's Sons.

Ferguson, Charles A. 1964, "Diglosia ", dalam Dell Hymes, Language in

Culture and Society, New York: Harper and Row Publisher.

Fernandez, Inyo Yos, 1996, Relasi Historis Kekerabatan Bahasa Flores,

Kajian Lingustik Historis Komparatif Terhadap Sembilan

Bahasa di Flores, Flores: Penerbit Nusa Indah

Gelb, IJ, 1963, A Study of Writing. The University of Chicago Press.

Gonda, J, 1952, Sanskrit in Indonesia, Den Haag : Uitgave van Oriental

Eookshop, Noordeinde

Istiawan, Budi, 1991, "Penulis dan Prosedur Penulisan Prasasti di Jawa

Abad IX - X Masehi", Skripsi, Yogyakarta : Fakultas Sastra,

Universitas Gadjah Mada Yogyakarta

Kartakusuma, Richadiana.1988. "Persebaran Prasasti Berbahasa Melayu

Kuna di Pulau Jawa", makaiah dalam EHPA 16-20 Februari,

Cipayung, 1998

Keraf, Gorys, 1995, Lingusitik Bandingan Historis, Jakarta : Penerbit

PT. Gramedia

Liliweri, Alo, 2001, Gatra Gatra Komunikasi Antar Budaya, Yogyakarta :

Pustaka Pelajar,

Mahsun, 1995, Dialektologi Diakronis Suatu Pengantar, Yogyakarta :

Gadjah Mada University Press

Molen, W. van der. 1985 "Sejarah dan Perkembangan Aksara Jawa" dalam

Soedarsono et.al (ed), Aksara dan Ramalan Nasib Dalam

Kebudayaan Jawa, Departemen Pendidikan dan Kebudayaan, Yogyakarta, 1985

Nababan, P.W.J, 1991, Sosiolingustik Suatu Pengantar, Jakarta

Penerbit Gramedia 
Nothofer, Bernd, 1975, The Reconstruction of Proto Malayo Javanic, s'Gravenhage : Martinus Nijhoff,.

Sedyawati, Edi, 1986, "Kajian Kuantitatif Atas Masalah Local Genius ", dalam PIA IV 3-9 Maret, Cipanas,

Sharma, Mukunda Madhava, 1985, Unsur-Unsur Bahasa Sanskerta Dalam Bahasa Indonesia, Denpasar : Wyâsa Sanggraha,

Soebadio, Haryati, 1987, "Hubungan Antar Kebudayaan ", dalam Muhadjir ( ed.), Evaluasi dan Strategi Kebudayaan, Jakarta : Fakultas Sastra Universitas Indonesia.

Suhardi, Basuki, 1996, Sikap Bahasa, Jakarta : Fakultas Sastra Universitas Indonesia,

Zoetmulder, P.J, 1994, Kalangwan A Survey of Old Javanese Literature, diindonesiakan oleh Dick Hartoko, Kalangwan Sastra Jawa Kuno Selayang Pandang, Jakarta : Penerbit Djambatan. 